Original Paper

\title{
Allogenic Natural Killer Cell Immunotherapy Combined with Irreversible Electroporation for Stage IV Hepatocellular Carcinoma: Survival Outcome
}

\author{
Mohammed Alnaggara Mao Lin ${ }^{c, d} \quad$ Adnan Mesmare Shuzhen Liangd,e \\ Ammar Qaid $^{\mathrm{b}} \quad$ Kecheng Xub ${ }^{\mathrm{b}, \mathrm{c}} \quad$ Jibing Chen ${ }^{\mathrm{d}, \mathrm{e}} \quad$ Lizhi Niu $^{\mathrm{b}, \mathrm{c}, \mathrm{d}} \quad$ Zhinan Yin ${ }^{\mathrm{a}}$ \\ aBiomedical Translational Research Institute and the First Affiliated Hospital, Jinan University, \\ Guangzhou, 'Department of Oncology, Fuda Cancer Hospital, Jinan University School, Guangzhou, \\ 'Department of Biological Treatment Center, Fuda Cancer Hospital, Jinan University School, Guangzhou, \\ 'Fuda Cancer Institute, Guangzhou, eDepartment of General surgery, Union Hospital , Tongji Medical \\ College, Huazhong University of Science and Technology, Wuhan, China
}

\section{Key Words}

Irreversible electroporation - Allogenic natural killer cell - Hepatocellular cancer - Adverse effects $\cdot$ Median overall survival.

\begin{abstract}
Background/Aims: We evaluated the clinical effectiveness of irreversible electroporation (IRE) in combination with immunotherapy using allogenic natural killer cells (NK) for stage IV hepatocellular carcinoma (HCC). Methods: The study involved 40 patients with stage IV HCC who were divided equally into two groups: 1) simple IRE; and 2) IRE plus allogenic NK cells (IRE-NK); we mainly assessed the overall survival (OS). Results: The effect of the IRE-NK treatment was synergistic, i.e., not only did it enhance immune function, it also decreased alpha-fetoprotein expression and showed significantly good clinical effectiveness. At the median 7.6-month follow-up (range, 3.8-12.1 months), median OS was higher in the IRENK group (10.1 months) than in the IRE group (8.9 months, $\mathrm{P}=0.0078)$. Conclusion: IRE combined with allogeneic NK cell immunotherapy significantly increases the median OS of patients with stage IV HCC.

(C) 2018 The Author(s)

M. Alnaggar and M. Lin contributed equally to this work. 


\section{Cellular Physiology Cell Physiol Biochem 2018;48:1882-1893

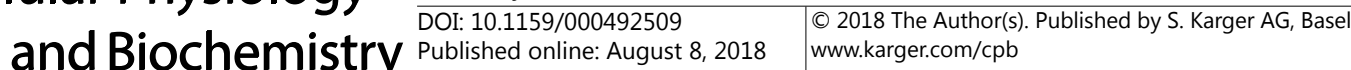

Alnaggar et al.: Allogenic NK Combined with IRE for Stage IV HCC

\section{Introduction}

Hepatocellular carcinoma (HCC) is one of the most common tumors worldwide, and its incidence is increasing [1]. In $80 \%$ of patients, HCC is associated with chronic liver diseases such as hepatitis or cirrhosis, which have major effects on prognosis and therapeutic preferences [2]. Non-surgical percutaneous ablation therapy such as percutaneous ethanol injection, microwave coagulation, and radiofrequency ablation (RFA) have been introduced and currently play an important role in HCC treatment $[3,4]$.

Irreversible electroporation (IRE) is a newly developed non-thermal ablation procedure. It uses millisecond electrical pulses to induce nanoscale defects that increase cell membrane permeability. The procedure induces apoptosis without harming the extracellular matrix; as a result, the structural components of the tissues are preserved [5].

In recent years, the rapid development and clinical translation of cancer immunology and cell culture technology has seen the emergence of cellular immunotherapy, a safe and effective treatment that is playing an increasingly important role in comprehensive treatment for cancer and that is evolving into the fourth major treatment modality for cancer behind surgery, chemotherapy, and radiotherapy [6-8]. Adjuvant cellular immunotherapy, e.g., that uses natural killer (NK) cells, are critical innate immune system components; they are essential in early host anti-cancer defense [9]. As the field of NK cell biology has progressed and the elucidation of NK function has advanced, encouraging anti-tumor effects on several cancers by adoptive NK cell transfer [10], such as in liver cancer [11-13], have been reported.

We performed the present retrospective study to compare how combined comprehensive IRE plus NK cell immunotherapy and IRE alone would affect hepatic tumors. For liver tumors of diameter $>5 \mathrm{~cm}$; initial treatment with transarterial chemoembolization (TACE) was performed once or twice to debulk the tumor to $5 \mathrm{~cm}$. We used post-diagnosis overall survival (OS) as the chief evaluation index for measuring the survival time of patients with stage IV HCC; adverse effects were recorded and classified in accordance with the Common Terminology Criteria of Adverse Events (CTCAE) v4.0.

\section{Materials and Methods}

Ethical Standards

All procedures performed in studies involving human participants were in accordance with the ethical standards of Guangzhou Fuda Cancer Hospital ethics committee and with the 1964 Declaration of Helsinki.

Ethics

The Regional Ethics Committee of Guangzhou Fuda Cancer Hospital, China, granted ethical approval for the study protocol. Written informed consent was obtained from every participant in accordance with the Declaration of Helsinki.

\section{Patient selection}

Between October 2015 and July 2017, 40 patients with stage IV HCC were enrolled in the study. The patients were divided equally into IRE and IRE plus NK cell (IRE-NK) treatment groups.

The enrolled patients met the following eligibility criteria: 1 2 significant liver tumors; surgery and chemotherapy were deemed unsuitable in any of the following situations: Karnofsky performance status (KPS) score $\geq 70$, white blood cell count $\geq 3 \times 10^{9} / \mathrm{L}$, neutrophil count $\geq 2 \times 10^{9} / \mathrm{L}$, hemoglobin $\geq 90 \mathrm{~g} / \mathrm{L}$, platelet count $\geq 100 \times 10^{9} / \mathrm{L}$, prothrombin time (international normalized ratio: INR) $\geq 1.5$ (with no severe coronary heart disease, myelosuppression, respiratory disease, and/or acute/chronic infection), level 3 hypertension, and adequate hepatic function (total bilirubin [T.BIL] $<75 \mu \mathrm{mol} / \mathrm{L}$, direct bilirubin [D.BIL] < $39 \mu \mathrm{mol} / \mathrm{L}$, and Child-Pugh score of A or B) and renal function (serum creatinine $<130 \mu \mathrm{M}$, serum urea $<$ $10 \mathrm{mM})$.

\section{KARGER}




\section{Cellular Physiology Cell Physiol Biochem 2018;48:1882-1893 \begin{tabular}{ll|l} 
DOI: 10.1159/000492509 & Ond Biochemistry \\
Published online: August 8, 2018 & $\begin{array}{l}\text { O } 018 \text { The Author(s). Published by S. Karger AG, Basel } \\
\text { www.karger.com/cpb }\end{array}$ \\
\cline { 2 - 3 }
\end{tabular}}

Alnaggar et al.: Allogenic NK Combined with IRE for Stage IV HCC

IRE

The patients were subjected to gastric decompression plus endotracheal intubation. General anesthesia was induced. Computed tomography (CT) was undertaken; the target region was demarcated. Ultrasound was used to guide the insertion of 2-3 electrodes. Another CT image was taken to confirm correct electrode placement, and then IRE was synchronized to deliver electrical pulses coordinated with cardiac rhythm to prevent cardiac dysrhythmia.

Typically, the electrodes were $1.5-2 \mathrm{~cm}$ apart. One or more pullbacks were performed if the target region was $>2 \mathrm{~cm}$ in diameter. The baseline and highest heart rate were recorded during IRE by electrocardiography, and subsequently, any arising arrhythmias were documented.

For precise monitoring of systolic blood pressure (SBP), we performed invasive blood pressure measurement via the femoral artery; if the SBP was $>40 \mathrm{mmHg}$ during ablation or $>190 \mathrm{mmHg}$ at any given time, the electrical pulses were suspended for 2-3 min. If there was no obvious decrease in SBP after 2-3 min, 2-5 mg phentolamine was administered.

After covering the entire tumor region, a repeat CT of the upper abdomen was performed to secure bleeding, pneumothorax, and/or other acute complications. Eventually, the patient was awakened by the anesthesiologist and observed overnight in the intensive care unit.

One day after IRE, the patients were moved to the general ward once we had confirmed that there were no acute complications. However, if such complications occurred, symptomatic treatment was initiated.

\section{NK cell therapy}

For NK cells culture, after isolated PBMC from whole blood, using the Human HANK Cell In vitro Preparation Kit (Hank Bioengineering Co., Ltd, Shenzhen, China), including the lethally radiated K562mb15-41BBL (K562D2) stimulatory cells [14], plasma treatment fluid, lymphocyte culture fluid additives, serum-free medium additives and cell infusion additives. It is dedicated for the expansion and activation of NK cells in peripheral blood or umbilical cord blood mononuclear cells in vitro, the preparation of NK cells with higher quantity, purity and activity, namely HANK cells [15]. The final cell count and quality control inspection were performed at day 9 of culture, and the qualified indicators included proportion of living cells $\geq 90 \%$, proportion of CD56+CD3- cells $\geq 85 \%$ (detection by flowcytometry was shown previously [15]), endotoxin content $\leq 1 \mathrm{EU} / \mathrm{ml}$, cell viability $\geq 80 \%$ (K562 cells were used as target cells, cytotoxicity assay was shown previously [15]), Bacteria, fungi and mycoplasma culture negative.

$80 \mathrm{ml}$ peripheral blood from allogenic donors was drawn 7 days before IRE and the immunotherapy was given 3 days after IRE. Approximately 8-10 billion HANK cells may be harvested after culture from $80 \mathrm{ml}$ of peripheral blood. After 12 days of cell culture, the NK cells were divided into three groups and intravenously infused into the patients from Day 13 to 15 . All cell preparation processes were performed by the same technician and assessed by another technician. Each patient must two cycles NK therapy continuously as a course.

For donor selection, the killer cell immunoglobulin-like receptors (KIRs) genotyping should be mismatched to the human leukocyte antigen (HLA) class I molecules of the patient [15-19]. We used PCRSSP to detect the KIR/HLA-Cw which can get the result on the day.

\section{TACE}

Twenty-five patients with hepatic tumors of $>5$-cm diameter underwent TACE as described previously [20-22]. A second TACE was performed if the tumor showed no shrinkage 2 weeks after the first procedure. Here, the therapeutic protocol dictated that large hepatic tumors ( $\geq 5 \mathrm{~cm}$ diameter) be treated initially with TACE and that considerable size reduction be observed prior to IRE.

\section{IRE-NK therapy}

All of the enrolled patients' kinsfolk were informed, and the peripheral blood was collected for NK cell isolation 7 days before IRE. IRE was carried out on day 9, and the cultured NK cells were infused intravenously from days 13 to 15 (Fig 1). 


\section{Cellular Physiology Cell Physiol Biochem 2018;48:1882-1893 \begin{tabular}{l|l|l} 
and Biochem 10.1159/000492509 & $\begin{array}{l}\text { (c) } 2018 \text { The Author(s). Published by S. Karger AG, Basel } \\
\text { www.karger.com/cpb }\end{array}$
\end{tabular}

Safety evaluation index

Adverse events and complications

All adverse events and complications were observed closely as we have described previously [14].

\section{Curative effect evaluation index}

Immune function

$2 \mathrm{~mL}$ peripheral blood was drawn to detect immune function and was assessed using flow cytometry (FACSCanto $^{\mathrm{TM}}$ II; BD, Grand Island, NY, USA). The tested indices included lymphocyte number and function in the patients' peripheral blood. BD multitest 6-color TBNK reagent (no. 644611) was used to detect the number of $\mathrm{CD}^{+} \mathrm{CD} 4{ }^{+}$cells $(95 \%$ range: $441-2156 / \mu \mathrm{L}), \mathrm{CD}^{+} \mathrm{CD}^{+}$cells $(95 \%$ range: $125-1312 / \mu \mathrm{L})$, total $\mathrm{CD}^{+}$cells $(95 \%$ range: $603-2990 / \mu \mathrm{L}), \mathrm{CD} 3 \mathrm{CD}^{-} 9^{+}$cells $(95 \%$ range: $107-698 / \mu \mathrm{L})$, and $\mathrm{CD} 3{ }^{-} \mathrm{CD} 16^{+} \mathrm{CD} 56^{+}$ cells (95\% range: 95-640/ $\mu \mathrm{L}$ ). BD Cytometric Bead Array Human Th1/Th2 Cytokine Kit II (no. 551809) was used to detect the expression levels of interleukin-2 (IL-2; 95\% range: 8-12.5 pg/mL), IL-4 (95\% range: 3.5$6 \mathrm{pg} / \mathrm{mL}$ ), IL-6 (95\% range: $2.7-8.5 \mathrm{pg} / \mathrm{mL}$ ), IL-10 (95\% range: $1.8-4 \mathrm{pg} / \mathrm{mL}$ ), tumor necrosis factor (TNF; $95 \%$ range: $1.7-2.5 \mathrm{pg} / \mathrm{mL}$ ), and interferon- $\gamma(\mathrm{IFN}-\gamma ; 95 \%$ range: $1.5-4 \mathrm{pg} / \mathrm{mL})$. The tests were performed according to the protocols in the instruction manuals. Results above or within the reference range were defined as normal immune function; one or more results below the reference range were defined as immune dysfunction. Peripheral blood drawn was 1 day before IRE and 3 days after IRE or IRE-NK.

\section{Circulating tumor cell (CTC) test}

Approximately $7.5 \mathrm{ml}$ blood was drawn by vein puncture from the 40 patients. The samples were stored at room temperature and processed within $6 \mathrm{~h}$ after collection. Briefly, mononuclear cells were separated from other blood components using human peripheral blood lymphocyte separation liquid (Tianjin Haoyang Biological Manufacture Co., Ltd, Tianjin, China) and centrifuged at $1800 \mathrm{~g}$ for $20 \mathrm{~min}$ at $4^{\circ} \mathrm{C}$. Interface cells were removed and washed, and red blood cells were removed using BD Pharm Lyse ${ }^{\mathrm{TM}}$ (Becton Dickinson, San Jose, CA, USA).

After separation of blood using human peripheral blood lymphocyte separation liquid, mononuclear cells were washed twice with sterile Hank's balanced salt solution (Life Technologies, Shanghai, China). Isolated cells were enriched by binding to magnetic CD326 (Ep-CAM) MicroBeads (Miltenyi Biotech Ltd, Bergisch Gladbach, Germany) using magnetic activated cell sorting (MACS). Enriched isolated cells were then labeled with monoclonal antibodies targeting the epithelial cell antigens CD45, CD326 and cytokeratin8, 18 and 19 (Miltenyi Biotech Ltd) and incubated in the dark at room temperature for $12 \mathrm{~min}$. Antibodies specific for leukocytes (CD45) labeled with phycoerythrin (10 ml), specific for epithelial cells (cytokeratin8, 18 and 19) labeled with fluorescein isothiocyanate $(10 \mathrm{ml})$ and specific for epithelial cells (CD326/Ep-CAM) labeled with allophycocyan $(10 \mathrm{ml})$ were added per $7.5 \mathrm{ml}$ whole blood. Cell pellets were resuspended in $500 \mathrm{ml}$ PBS and counted by flow cytometry using a BD FACSCanto ${ }^{\mathrm{TM}}$ II apparatus (Becton Dickinson, San Jose, CA, USA). Cells that were CD45 negative, CK positive and CD326 positive were defined as CTCs.

\section{Assessment of hepatic functional reserve}

Blood samples were obtained from the patients in the morning after overnight fasting. Testing was performed every 1-3 days until the patients were discharged. Five time points were used: 1 day before IRE and $1,3,7$, and 30 days postoperatively. Hepatic function was determined with a Hitachi 7100 automated biochemical analyzer (Tokyo, Japan) and commercial kits (BioSino Bio-Technology and Science Inc., Beijing, China). The normal ranges for the measured parameters are as follows: alanine aminotransferase (ALT), 


\section{Cellular Physiology Cell Physiol Biochem 2018;48:1882-1893 \begin{tabular}{ll|l} 
DOI: 10.1159/000492509 & and Biochemistry Published online: August 8, 2018 & $\begin{array}{l}\text { O 2018 The Author(s). Published by S. Karger AG, Basel } \\
\text { www.karger.com/cpb }\end{array}$
\end{tabular} \\ Alnaggar et al.: Allogenic NK Combined with IRE for Stage IV HCC}

5-40 U/L; aspartate aminotransferase (AST), 8-40 U/L; T.BIL, 0-25.5 $\mu \mathrm{mol} / \mathrm{L}$; and D.BIL, 0-13 $\mu \mathrm{mol} / \mathrm{L}$. Values above the upper limit of the normal range indicated abnormal hepatic function.

Alpha-fetoprotein (AFP)

Serum was harvested 1 day before treatment and 3 days, 1 month, and 3 months after treatment. Serum AFP was detected using an electrochemical luminescence immunity analyzer and accessory kit (Roche Cobase 411). AFP normal range: $0-20 \mathrm{ng} / \mathrm{ml}$.

\section{Imaging change}

The treatment results were evaluated by imaging changes in the largest transverse diameter. The total areas of all tumors were compared before and after treatment. The recent curative effect had to be maintained for more than 4 weeks.

\section{Follow-up}

The patients underwent plain CT and enhanced CT 1 week before treatment, and were followed at 1 and 2 months after treatment. The endpoint of interest was OS.

We calculated the OS as the interval between the IRE or IRE-NK date and the date of any-cause death. We monitored the patients consistently post-treatment manually and using intelligent follow-up systems.

\section{Statistical analysis}

We recorded complications and classified them using CTCAE v4.0. We also evaluated local tumor control and OS.

We used criteria for image-guided tumor ablation to assess radiographic local tumor control [23]. We performed ultrasonography of the thorax and/or abdomen 1 day and 1 week after treatment. We performed follow-up dynamic CT at 1 month; subsequently, it was performed at 3-4-month intervals.

We compared the two groups' basic characteristics using the chi-square test; we report immunity detection data as the mean \pm standard deviation; we compared imaging changes using Student's $t$-test; we marked local and systemic adverse events in the nursing records, and the chi-square test was used to compare them.

We used Dunnett's test to compare the OS of the two groups. OS between the groups was compared with the Kaplan-Meier test with log-rank analysis. $\mathrm{P}<0.05$ or $\mathrm{P}<0.01$ indicated significant differences. We used GraphPad (GraphPad, San Diego, CA, USA) for the statistical analysis.

\section{Results}

\section{Clinical data}

In this study, 28 men and 12 women received IRE and/or TACE. The age range was 31-77 years; the mean age was 55 years. Twenty-five and three patients had a history of hepatitis B and C infection, respectively.

Seventeen patients had originally been treated with surgery; 15 patients had received systemic chemotherapy elsewhere; the 40 patients received further treatment at our hospital 5-12 months after diagnosis of stage IV HCC. The two groups' data were compared according to the American Joint Committee on Cancer (AJCC) 7th edition; their demographics did not differ statistically (Table 1).

\section{Safety evaluation}

All hepatic lesions were treated with IRE; sessions were performed successfully. No severe complications (such as ruptured or hepatic failure, myoglobinuria, or acute renal failure) were reported post-IRE. Several mild adverse effects occurred, but the affected patients eventually recovered with or without symptomatic management (Table 2). 
Table 1. Patient demographics. TACE, transarterial chemoembolization

\begin{tabular}{|c|c|c|c|}
\hline Patient characteristic before treatment & $\operatorname{IRE}(n=20)$ & IRE-NK $(n=20)$ & P-value \\
\hline Sex (Male/female) & $14 / 6$ & $13 / 7$ & $\mathrm{P}=0.891$ \\
\hline Median age $(y)$ & 56 & 61 & $P=0.702$ \\
\hline Child-Pugh stratification & & & $P=0.773$ \\
\hline Class A & 11 & 13 & \\
\hline Class B & 9 & 7 & \\
\hline Karnofsky performance status score & & & $P=0.564$ \\
\hline 70 & 11 & 10 & \\
\hline 80 & 6 & 5 & \\
\hline 90 & 3 & 5 & \\
\hline Hepatitis B-/C-positive & $14 / 2$ & $11 / 1$ & $P=0.654$ \\
\hline TACE & 17 & 16 & $P=0.885$ \\
\hline Tumor size $(\mathrm{cm})$ & & & $P=0.691$ \\
\hline$<5$ & 8 & 6 & \\
\hline$>5$ & 12 & 14 & \\
\hline
\end{tabular}

Table 2. Adverse events

\begin{tabular}{lccc}
\hline Adverse event & Cases (n) & Percentage (\%) & Grade \\
\hline Local reactions & 10 & 25.0 & 1 \\
Tussis & 5 & 12.5 & 1 \\
Nausea and emesis & 21 & 50.3 & 1 \\
Pain of puncture point & & & \\
Systemic reactions & 12 & 30.0 & 1 \\
Fatigue & 18 & 45.0 & 1 \\
Fever & 16 & 40.0 & 2 \\
Transient reduction of intraoperative blood pressure & 13 & 32.6 & 2 \\
White cell count reduction & & & \\
\hline
\end{tabular}

\section{Clinical efficacy}

Detection of immune function

We compared the lymphocyte count and function before and after treatment: all patients' pre-treatment data were merged and compared with post-treatment data (Table 3). The IRE-NK group had significantly higher lymphocyte subset counts after treatment, particularly NK cells $(\mathrm{P}<0.001)$; the group also had higher Th1-type cytokine levels, while that of Th2-type cytokines were largely unaffected. 


\section{Changes in CTC numbers}

Peripheral blood CTCs were analyzed in all 40 patients before and after HCC treatment (Fig 2). One day before IRE, the mean CTC number was $48.24 \pm 8.346$; at 7 and 30 days after treatment, the mean CTC number was $35.64 \pm 7.268$ and $19.54 \pm 6.312$, respectively; that for the IRE-NK group was $49.16 \pm 6.354,29.63 \pm 7.324$, and $15.92 \pm 5.648$, respectively. There was an obvious difference in CTC numbers between the two groups at 7 and 30 days after treatment $(\mathrm{P}<0.05)$.

\section{Changes in hepatic function}

In both groups, serum transaminase values increased promptly, peaking 1 day after treatment, and then declining steadily 3 and 7 days and 1 month after treatment (Fig 3). The two groups did not differ after treatment on day 3 and 7 (P > 0.05); however, the IRE-NK group had lower ALT and AST values 1 month after treatment compared to the IRE group (Fig $3 \mathrm{~A}, 3 \mathrm{~B} ; \mathrm{P}<0.05$ ). There was no obvious change in serum bilirubin between the two groups. The normal value of ALT is $5-40 \mathrm{U} / \mathrm{L}$, and $8-40 \mathrm{U} / \mathrm{L}$ to AST.
Table 3. Comparison of lymphocyte number and function

\begin{tabular}{|c|c|c|c|}
\hline Item & Pre-treatment $(\mathrm{n}=40)$ & $\operatorname{IRE}(\mathrm{n}=20)$ & IRE-NK $(n=20)$ \\
\hline \multicolumn{4}{|c|}{ Number (cells $/ \mu \mathrm{L}$ ): } \\
\hline Total T cell & $1531 \pm 42$ & $1612 \pm 61^{*}$ & $1845 \pm 86^{* *}$ \\
\hline $\mathrm{CD} 8+\mathrm{T}$ cell & $621 \pm 7$ & $709 \pm 22^{*}$ & $771 \pm 16^{* *}$ \\
\hline $\mathrm{CD} 4+\mathrm{T}$ cell & $708 \pm 36$ & $816 \pm 32^{*}$ & $834 \pm 31^{* *}$ \\
\hline NK cell & $372 \pm 28$ & $507 \pm 52^{*}$ & $724 \pm 51 * * *$ \\
\hline B cell & $324 \pm 20$ & $381 \pm 12$ & $387 \pm 11$ \\
\hline \multicolumn{4}{|c|}{ Function $(\mathrm{pg} / \mathrm{mL})$ : } \\
\hline IL-2 & $9.9 \pm 3.4$ & $15.9 \pm 3.7^{* *}$ & $21.9 \pm 4.1^{* * *}$ \\
\hline TNF- $\beta$ & $5.8 \pm 2.6$ & $10.0 \pm 2.1^{* * *}$ & $14.1 \pm 2.7^{* * *}$ \\
\hline IFN- $\gamma$ & $4.4 \pm 3.2$ & $11.2 \pm 3.4^{* *}$ & $17.2 \pm 6.1^{* * *}$ \\
\hline IL-4 & $10.2 \pm 2.1$ & $10.1 \pm 3.4$ & $11.2 \pm 3.6$ \\
\hline IL-6 & $13.2 \pm 3.9$ & $15.2 \pm 4.5$ & $14.5 \pm 7.1$ \\
\hline IL-10 & $9.2 \pm 2.6$ & $9.6 \pm 2.4$ & $10.2 \pm 3.1$ \\
\hline
\end{tabular}

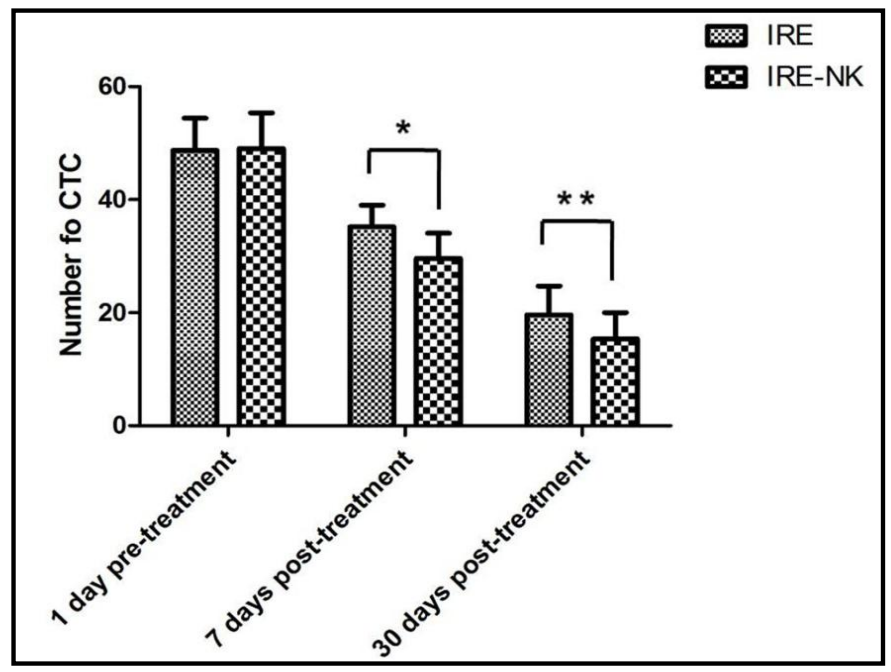

Fig. 2. Changes in CTC numbers. Peripheral blood CTCs were analyzed in all 40 patients before and after HCC treatment. The CTC numbers were obviously different between the two groups 7 and 30 days after treatment $(\mathrm{P}<0.05)$.
Fig. 3. Changes in hepatic function. In both groups, serum transaminase values increased promptly to peak 1 day after treatment, and steadily declined 3 and 7 days and 1 month after treatment in both groups. One month after treatment, ALT and AST values were lower in the IRE-NK group than in the IRE group $(\mathrm{P}<0.05)$.

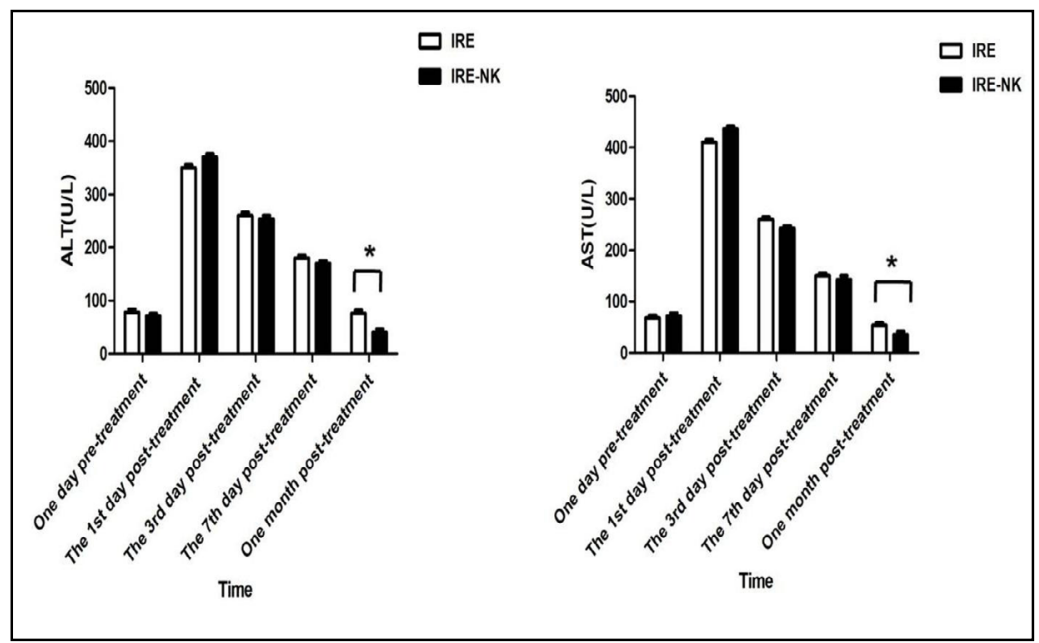




\section{Changes in AFP}

In both groups, AFP expression was higher than normal 1 day before treatment and decreased gradually 3 days and 1 month and 3 months after treatment (Fig 4). There was no difference between the groups 3 days after treatment $(\mathrm{P}>0.05)$, but at 1 month and 3 months after treatment, AFP expression was obviously lower in the IRE-NK group (Fig 4, P < 0.01), even though 11 who patients received IRK-NK therapy had normal-range values.

\section{Clinical response}

The clinical response was observed 3 months after treatment. Table 4 lists the transverse diameters (maximum). Both groups had visibly decreased tumor volume after treatment; however, the IRENK group had a smaller maximum tumor diameter than the IRE group 3 months after treatment $(\mathrm{P}<0.01)$. No patient died during follow-up; six patients in the IRE group and two patients in the IRE-NK group had progressive disease (PD) $(\mathrm{P}<0.05$, Table 5). The IRE-NK group had a higher disease control rate (DCR) (90\%) than the IRE group $(75 \%, \mathrm{P}<$ 0.01 ), but relative risk (RR) between the groups did not differ $(\mathrm{P}>0.05)$.

Fig 5 shows the representative results of two patients after 3 months treatment in the IRE-NK group. Patient 1, admitted in Fuda cancer hospital in April 2016, male, 44 years old, stage IV, $3.5 \mathrm{~cm}$ maximum HCC nodule (A). There is no enhancement in the occupying lesion (C); there was mild shrinkage of the area. Patient 2, admitted in Fuda cancer hospital in July 2016, female, 52 years old, stage IV, $3.0 \mathrm{~cm}$ maximum HCC nodule (A). There is a lesion with a large necrotic area (C).

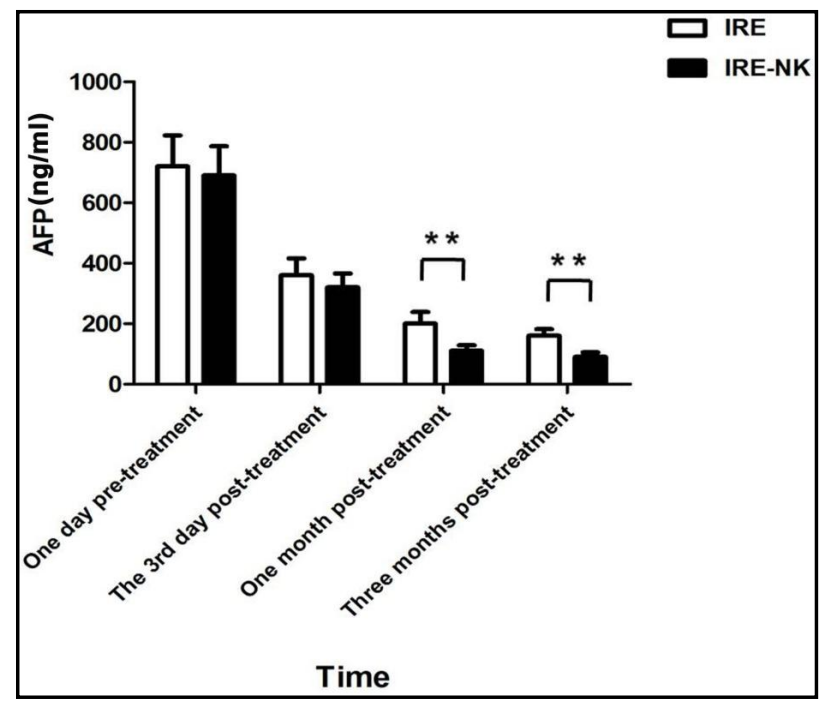

Fig. 4. Changes in AFP. AFP was tested in 40 patients, and the expression of AFP was higher than normal 1 day before treatment and declined steadily 3 days, and 1 and 3 months after treatment in both groups. The IRE-NK group had obviously lower AFP at 1 and 3 months after treatment $(\mathrm{P}<0.01)$.

Table 4. Maximum transverse diameter of lesions pre- and post-treatment

\begin{tabular}{lccc}
\hline Time & Maximum diameter $(\mathrm{mm})$ & & P-value \\
\hline & IRE & IRE-NK & \\
Pre-treatment & $3.68 \pm 1.02$ & $3.59 \pm 1.38$ & $\mathrm{P}>0.05$ \\
1 month post-treatment & $3.12 \pm 1.00$ & $3.07 \pm 1.24$ & $\mathrm{P}>0.05$ \\
3 months post-treatment & $2.68 \pm 1.01$ & $2.31 \pm 0.68$ & $\mathrm{P}<0.05$ \\
\hline
\end{tabular}

Table 5. Clinical response between the two groups 3 months post-treatment. Clinical responses were evaluated according to Response Evaluation Criteria in Solid Tumors (version 1.1). CR, complete response; $P R$, partial response; $S D$, stable disease; PD, progressive disease; $R R$, response rate; $D C R$, disease control rate

\begin{tabular}{lcccc}
\hline & Total & IRE & IRE-NK & P value \\
\hline Number & 40 & 20 & 20 & $\mathrm{P}>0.05$ \\
CR & 9 & 4 & 5 & $\mathrm{P}>0.05$ \\
PR & 15 & 7 & 8 & $\mathrm{P}>0.05$ \\
SD & 9 & 4 & 5 & $\mathrm{P}>0.05$ \\
PD & 7 & 5 & 2 & $\mathrm{P}<0.05$ \\
RR (\%) & 60.0 & 55.0 & 65.0 & $\mathrm{P}>0.05$ \\
DCR (\%) & 82.5 & 75.0 & 90.0 & $\mathrm{P}<0.01$ \\
\hline
\end{tabular}




\section{Cellular Physiology Cell Physiol Biochem 2018;48:1882-1893 \begin{tabular}{l|l|l} 
and Biochemistry 2018 The Author(s). Published by S. Karger AG, Basel \\
DOI: 10.1159/000492509
\end{tabular}

Follow-up

At the last follow-up date, the median OS in the IRE-NK and IRE group was 10.1 and 8.9 months, respectively. The IRE-NK group had significantly longer OS than the IRE group $(\mathrm{P}<0.01$, Fig 6).

\section{Discussion}

The majority of patients with advanced hepatic cancer have unresectable tumors $[24,25]$. The treatment options for patients with stage IV hepatic tumors are chemoembolization, RFA, chemotherapy, targeted therapy, and other palliative therapies [26]. Thermal ablation with RFA or microwave ablation (MWA) is the standard of care therapy for selected small hepatocellular cancers not responsive to surgical resection [27], but heat sink and collateral damage are its limitations [28].

IRE uses a high-voltage field to create nanopores in the target cell membrane, which disrupts the internal and external homeostasis and consequently kills the cell via apoptosis; adjacent tissues, e.g., the nerves, vessels, gallbladder, and bile duct, are not affected by heat sink and it may result in less collateral damage based on its mechanism of action. Moreover, it has the potential to preserve venous structures in close proximity to the ablation zones.

IRE is practical and safe for ablation in hepatic adenocarcinoma [29]. In a prospective, nonrandomized study, Cheung et al [30]. reported their experience treating 18 HCC lesions in 11 patients. No serious complications were reported despite seven of 18 lesions being adjacent to important structures or organs (i.e., portal vein, hepatic vein, heart, colon, duodenum, and gallbladder). On unresectable and metastatic pancreatic cancers, the results are promising, with markedly increased clinical efficacy and OS [31].

Here, CT after treatment showed that the gallbladder, bile duct, and surrounding tissues were unaffected by IRE. The effectiveness and safety outcomes of IRE were good. However, metastases are present in the great majority of patients with stage IV disease; therefore, IRE is only able to treat the primary tumors and has a limited possible beneficial role against advanced metastasis of hepatic tumor cell metastasis. Furthermore, hematogenous spread is an important avenue of promoting HCC metastasis; the distant metastasis theory states that hepatic cells are introduced by micrometastases to the surrounding tissues, lymph

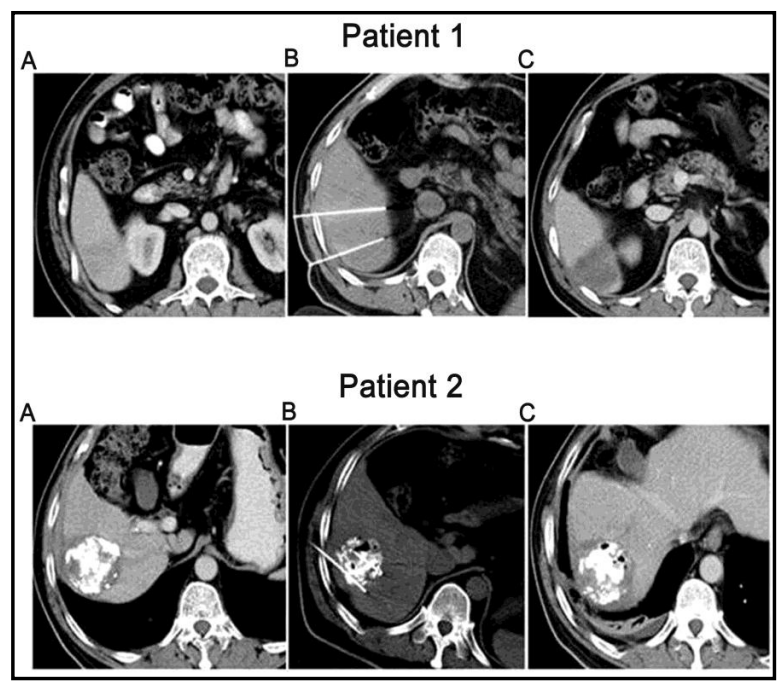

Fig. 5. Magnetic resonance imaging (MRI) images of 2 representative cases with complete response (CR) 3 months after IRE-NK. Patient 1, admitted in Fuda cancer hospital in April 2016, male, 44 years old, stage IV, 3.5 $\mathrm{cm}$ maximum HCC nodule. There is no enhancement in the occupying lesion; there was mild shrinkage of the area. Patient 2, admitted in Fuda cancer hospital in July 2016, female, 52 years old, stage IV, $3.0 \mathrm{~cm}$ maximum HCC nodule. There is a lesion with a large necrotic area.

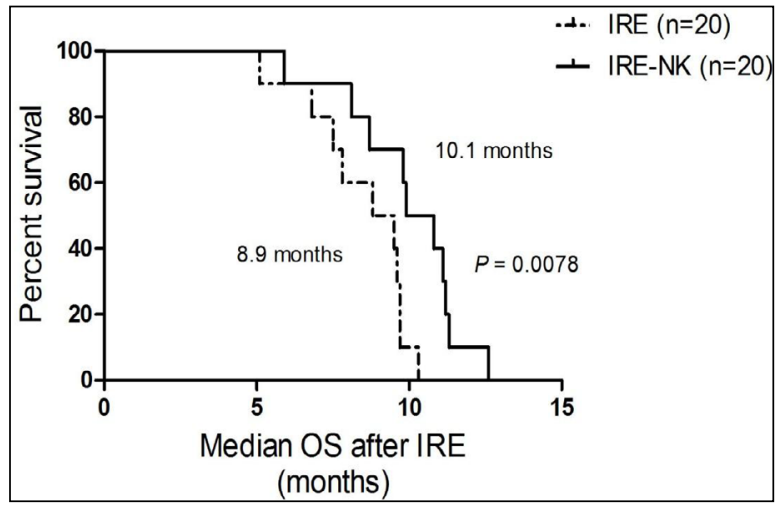

Fig. 6. Correlation of median OS with treatment type. The IRE-NK group had significantly longer OS than the IRE group $(\mathrm{P}<0.01)$. 
nodes, and peripheral blood, and consequently are able to reach any tissue or organ. Hence, after IRE, we administered NK cell infusion to the patients according to the objectives of our research; subsequently, the IRE-NK cell combination had a remarkable synergistic effect, and greatly improved the anti-tumor effects, augmenting the patients' immune functions significantly and increasing $O S$, an apparent demonstration of the clear-cut improvements of the clinical efficacy. Furthermore, the patients tolerated the treatment well.

Numerous analyses in recent years have shown that tumor immune responses influence cancer formation and progression in advanced hepatic cancer [32], indicating the possible effectiveness of immune-based therapy as a cancer treatment option.

As a part of the innate immune response, NK cells recognize and lyse cells lacking major histocompatibility complex (MHC) molecules by activating their receptors, such as NKG2D, NKp30, NKp40, and NKp46. Consequently, tumor cells are more susceptible to NK cells due to the lack of MHC class I molecules [33].

NK cells express KIRs (killer cell immunoglobulin-like receptors), which prevents NK cells from killing tumor cells expressing their own MHC class I molecules. NK cells treatments can be autologous and allogeneic treatments. For example, only some patients with glioma achieve partial response (PR) following treatment with autologous NK cells [34]; yet, the same treatment resulted in no clinical effects in some patients with recurrent metastatic carcinomas and lymphoma $[35,36]$. Therefore, many studies in recent years have examined allograft NK cells (instead of self-NK cells) for exploring adoptive immunotherapy of cancer. Therefore, we focused on allogeneic NK cell therapy in the present study and achieved good results.

Currently, there is an ongoing series of allogeneic NK cell therapy clinical trials [37]. The in vitro amplification of allogeneic NK cells plus chemotherapy for ovarian cancer, breast cancer recurrent metastasis, and renal cell carcinoma has produced clinical curative effects [38-40].

\section{Conclusion}

In summary, our single-center, retrospective study demonstrates that allogeneic NK cell therapy plus percutaneous IRE benefits outcomes and improvement for patients with hepatic cancer, which yields a substantial therapeutic pattern for stage IV HCC.

\section{Acknowledgements}

We would like to thank the native English speaking scientists of Elixigen Company (Huntington Beach, California) for editing our manuscript. This work was supported by the NSF Major International Joint Research Program of China -(Grant no. 31420103901, 2015.01-2019.12) and International Foundation for Sciences of Guangzhou Fuda Cancer Hospital (Grant no. Y2016-ZD-007).

\section{Disclosure Statement}

The authors declare that there are no conflicts of interests. 


\section{Cellular Physiology Cell Physiol Biochem 2018;48:1882-1893 \begin{tabular}{ll|l} 
and Biochemistry Published online: August 8, 2018 & $\begin{array}{l}\text { (c) } 2018 \text { The Author(s). Published by S. Karger AG, Basel } \\
\text { www.karger.com/cpb }\end{array}$
\end{tabular}}

\section{References}

1 Ali AM, Lizhi N, Jialiang L, Fei Y, Yuan W, Jianying Z, Jin Y, Jibing C, Feng M, Kecheng X: Cryoprotective therapy for hepatocellular carcinoma: study of 51 patients with a single lesion. Cryobiology 2014;69:61-67.

- Alnaggar M, Niu L, Li J, Yao F, Wang Y, Zeng J, Ye J, Chen J, Mu F, Xu K: Cryoprotective therapy for huge hepatocellular carcinoma: a study of 14 patients with a single lesion. Cryobiology 2014;69:457-461.

-3 Zhen ZJ, Lau WY, Wang FJ, Lai EC: Laparoscopic liver resection for hepatocellular carcinoma in the left liver: Pringle maneuver versus tourniquet method. World J Surg 2010;34:314-319.

4 Seifert JK, Morris DL: World survey on the complications of hepatic and prostate cryotherapy. World J Surg 1999;23:109-113; 113-104.

-5 Edd JF, Horowitz L, Davalos RV, Mir LM, Rubinsky B: In vivo results of a new focal tissue ablation technique: irreversible electroporation. IEEE Trans Biomed Eng 2006;53:1409-1415.

-6 Aerts JG, Hegmans JP: Tumor-specific cytotoxic T cells are crucial for efficacy of immunomodulatory antibodies in patients with lung cancer. Cancer Res 2013;73:2381-2388.

7 Topalian SL, Hodi FS, Brahmer JR, Gettinger SN, Smith DC, McDermott DF, Powderly JD, Carvajal RD, Sosman JA, Atkins MB, Leming PD, Spigel DR, Antonia SJ, Horn L, Drake CG, Pardoll DM, Chen L, Sharfman WH, Anders RA, Taube JM, McMiller TL, Xu H, Korman AJ, Jure-Kunkel M, Agrawal S, McDonald D, Kollia GD, Gupta A, Wigginton JM, Sznol M: Safety, activity, and immune correlates of anti-PD-1 antibody in cancer. N Engl J Med 2012;366:2443-2454.

$>8$ Hasegawa T, Suzuki H, Yamaura T, Muto S, Okabe N, Osugi J, Hoshino M, Higuchi M, Ise K, Gotoh M: Prognostic value of peripheral and local forkhead box P3(+) regulatory T cells in patients with non-smallcell lung cancer. Mol Clin Oncol 2014;2:685-694.

-9 Cheng M, Chen Y, Xiao W, Sun R, Tian Z: NK cell-based immunotherapy for malignant diseases. Cell Mol Immunol 2013;10:230-252.

10 Pan K, Guan XX, Li YQ, Zhao JJ, Li JJ, Qiu HJ, Weng DS, Wang QJ, Liu Q Huang LX, He J, Chen SP, Ke ML, Zeng YX, Xia JC: Clinical activity of adjuvant cytokine-induced killer cell immunotherapy in patients with postmastectomy triple-negative breast cancer. Clin Cancer Res 2014;20:3003-3011.

-11 Yang L, Ren B, Li H, Yu J, Cao S, Hao X, Ren X: Enhanced antitumor effects of DC-activated CIKs to chemotherapy treatment in a single cohort of advanced non-small-cell lung cancer patients. Cancer Immunol Immunother 2013;62:65-73.

12 Li R, Wang C, Liu L, Du C, Cao S, Yu J, Wang SE, Hao X, Ren X, Li H: Autologous cytokine-induced killer cell immunotherapy in lung cancer: a phase II clinical study. Cancer Immunol Immunother 2012;61:21252133.

13 Han RX, Liu X, Pan P, Jia YJ, Yu JC: Effectiveness and safety of chemotherapy combined with dendritic cells co-cultured with cytokine-induced killer cells in the treatment of advanced non-small-cell lung cancer: a systematic review and meta-analysis. PLoS One 2014;9:e108958.

$\checkmark 14$ Imai C, Iwamoto S, Campana D: Genetic modification of primary natural killer cells overcomes inhibitory signals and induces specific killing of leukemic cells. Blood 2005;106:376-383.

15 Zhang M, Daniel S, Huang Y, Chancey C, Huang Q Lei YF, Grinev A, Mostowski H, Rios M, Dayton A: AntiWest Nile virus activity of in vitro expanded human primary natural killer cells. BMC Immunol 2010;11:3.

$\$ 16$ Witt CS, Christiansen FT: The relevance of natural killer cell human leucocyte antigen epitopes and killer cell immunoglobulin-like receptors in bone marrow transplantation. Vox Sang 2006;90:10-20.

-17 Forte P, Baumann BC, Schneider MK, Seebach JD: HLA-Cw4 expression on porcine endothelial cells reduces cytotoxicity and adhesion mediated by CD158a+ human NK cells. Xenotransplantation 2009;16:19-26.

18 Kunert K, Seiler M, Mashreghi MF, Klippert K, Schonemann C, Neumann K, Pratschke J, Reinke P, Volk HD, Kotsch K: KIR/HLA ligand incompatibility in kidney transplantation. Transplantation 2007;84:1527-1533.

19 Moretta L, Moretta A: Killer immunoglobulin-like receptors. Curr Opin Immunol 2004;16:626-633.

20 Fazio MJ, Olsen DR, Uitto JJ: Skin aging: lessons from cutis laxa and elastoderma. Cutis 1989;43:437-444.

21 Azizi A, Naguib NN, Mbalisike E, Farshid P, Emami AH, Vogl TJ: Liver metastases of pancreatic cancer: role of repetitive transarterial chemoembolization (TACE) on tumor response and survival. Pancreas 2011;40:1271-1275.

22 Liaw YF, Lin DY: Transcatheter hepatic arterial embolization in the treatment of hepatocellular carcinoma. Hepatogastroenterology 1990;37:484-488. 


\section{Cellular Physiology Cell Physiol Biochem 2018;48:1882-1893 \begin{tabular}{ll|l} 
DOI: 10.1159/000492509 & $\begin{array}{l}\text { O 2018 The Author(s). Published by S. Karger AG, Basel } \\
\text { www.karger.com/cpb }\end{array}$ \\
\hline
\end{tabular}}

-23 Goldberg SN, Grassi CJ, Cardella JF, Charboneau JW, Dodd GD, 3rd, Dupuy DE, Gervais D, Gillams AR, Kane RA, Lee FT, Jr., Livraghi T, McGahan J, Phillips DA, Rhim H, Silverman SG: Image-guided tumor ablation: standardization of terminology and reporting criteria. J Vasc Interv Radiol 2005;16:765-778.

-24 Endo I, Gonen M, Yopp AC, Dalal KM, Zhou Q, Klimstra D, D’Angelica M, DeMatteo RP, Fong Y, Schwartz L, Kemeny N, O’Reilly E, Abou-Alfa GK, Shimada H, Blumgart LH, Jarnagin WR: Intrahepatic cholangiocarcinoma: rising frequency, improved survival, and determinants of outcome after resection. Ann Surg 2008;248:84-96.

25 Fong Y, Sun RL, Jarnagin W, Blumgart LH: An analysis of 412 cases of hepatocellular carcinoma at a Western center. Ann Surg 1999;229:790-799; 799-800.

-26 Befeler AS, Di Bisceglie AM: Hepatocellular carcinoma: diagnosis and treatment. Gastroenterology 2002;122:1609-1619.

27 Poulou LS, Botsa E, Thanou I, Ziakas PD, Thanos L: Percutaneous microwave ablation vs radiofrequency ablation in the treatment of hepatocellular carcinoma. World J Hepatol 2015;7:1054-1063.

-28 Zimmerman A, Grand D, Charpentier KP: Irreversible electroporation of hepatocellular carcinoma: patient selection and perspectives. J Hepatocell Carcinoma 2017;4:49-58.

29 Sanchez-Velazquez P, Castellvi Q, Villanueva A, Quesada R, Panella C, Caceres M, Dorcaratto D, Andaluz A, Moll X, Trujillo M, Burdio JM, Berjano E, Grande L, Ivorra A, Burdio F: Irreversible electroporation of the liver: is there a safe limit to the ablation volume? Sci Rep 2016;6:23781.

-30 Cheung W, Kavnoudias H, Roberts S, Szkandera B, Kemp W, Thomson KR: Irreversible electroporation for unresectable hepatocellular carcinoma: initial experience and review of safety and outcomes. Technol Cancer Res Treat 2013;12:233-241.

-31 Zhang Y, Shi J, Zeng J, Alnagger M, Zhou L, Fang G, Long X, Pan Z, Li Y, Chen J, Xu K, Qian W, Niu L: Percutaneous Irreversible Electroporation for Ablation of Locally Advanced Pancreatic Cancer: Experience From a Chinese Institution. Pancreas 2017;46:e12-e14.

-32 Eggert T, Greten TF: Tumor regulation of the tissue environment in the liver. Pharmacol Ther 2017;173:4757.

33 Dahlberg CI, Sarhan D, Chrobok M, Duru AD, Alici E: Natural Killer Cell-Based Therapies Targeting Cancer: Possible Strategies to Gain and Sustain Anti-Tumor Activity. Front Immunol 2015;6:605.

-34 Ishikawa E, Tsuboi K, Saijo K, Harada H, Takano S, Nose T, Ohno T: Autologous natural killer cell therapy for human recurrent malignant glioma. Anticancer Res 2004;24:1861-1871.

-35 Burns LJ, Weisdorf DJ, DeFor TE, Vesole DH, Repka TL, Blazar BR, Burger SR, Panoskaltsis-Mortari A, Keever-Taylor CA, Zhang MJ, Miller JS: IL-2-based immunotherapy after autologous transplantation for lymphoma and breast cancer induces immune activation and cytokine release: a phase I/II trial. Bone Marrow Transplant 2003;32:177-186.

-36 deMagalhaes-Silverman M, Donnenberg A, Lembersky B, Elder E, Lister J, Rybka W, Whiteside T, Ball E: Posttransplant adoptive immunotherapy with activated natural killer cells in patients with metastatic breast cancer. J Immunother 2000;23:154-160.

-37 Koehl U, Kalberer C, Spanholtz J, Lee DA, Miller JS, Cooley S, Lowdell M, Uharek L, Klingemann H, Curti A, Leung W, Alici E: Advances in clinical NK cell studies: Donor selection, manufacturing and quality control. Oncoimmunology 2016;5:e1115178.

38 Geller MA, Cooley S, Judson PL, Ghebre R, Carson LF, Argenta PA, Jonson AL, Panoskaltsis-Mortari A, Curtsinger J, McKenna D, Dusenbery K, Bliss R, Downs LS, Miller JS: A phase II study of allogeneic natural killer cell therapy to treat patients with recurrent ovarian and breast cancer. Cytotherapy 2011;13:98-107.

-39 Godal R, Bachanova V, Gleason M, McCullar V, Yun GH, Cooley S, Verneris MR, McGlave PB, Miller JS: Natural killer cell killing of acute myelogenous leukemia and acute lymphoblastic leukemia blasts by killer cell immunoglobulin-like receptor-negative natural killer cells after NKG2A and LIR-1 blockade. Biol Blood Marrow Transplant 2010;16:612-621.

40 Cooley S, Burns LJ, Repka T, Miller JS: Natural killer cell cytotoxicity of breast cancer targets is enhanced by two distinct mechanisms of antibody-dependent cellular cytotoxicity against LFA-3 and HER2/neu. Exp Hematol 1999;27:1533-1541. 